\title{
Reproduction of the Brazilian snapper, Lutjanus alexandrei Moura \& Lindeman, 2007 (Perciformes: Lutjanidae), off the northern coast of Pernambuco, Brazil
}

\author{
Cezar A. F. Fernandes, Paulo G. V. de Oliveira, Paulo E. P. Travassos \\ and Fábio H. V. Hazin
}

Reproductive aspects of the Brazilian snapper Lutjanus alexandrei, were characterized, including a description of the development of oocytes and spermatogenic cells, size at first sexual maturity, and fecundity. A total of 540 fish were analyzed with 250 having their gonads sectioned to allow microscopic evaluation. Six maturity stages were identified for females and males: immature, maturing, mature, spawning, spawned, and resting. Fish standard length (SL) varied from 13.0 to $28.3 \mathrm{~cm}$ and sex ratio was 1.6 males: 1.0 females. Monthly distributions of mean Gonadosomatic Index (GSI) and maturity stages suggest that spawning occurs mainly in a protracted period, during the warmer months, from November to March. The size of first sexual maturity was estimated at $17.1 \mathrm{~cm}$ SL for females and $16.8 \mathrm{~cm}$ SL for males. Oocyte development suggests that $L$. alexandrei exhibits a multiple batch spawning behavior and batch fecundity varied from 34,000 to 324,000 oocytes.

Os aspectos reprodutivos da baúna-de-fogo Lutjanus alexandrei foram caracterizados, incluindo a descrição do desenvolvimento dos ovócitos e células espermatogênicas, do tamanho de primeira maturação sexual, e da fecundidade. Um total de 540 peixes foi analisado, dos quais 250 tiveram as suas gônadas seccionadas para avaliação microscópica. Seis estágios de maturidade sexual foram determinados para fêmeas e machos: imaturo, em maturação, maduro, desovando, desovado e repouso. O comprimento padrão (CP) dos peixes variou de 13,0 a 28,3 cm e a proporção sexual foi de 1,6 machos: 1,0 fêmeas. As distribuições mensais dos valores médios do Índice Gonadosomático (IGS) e dos estágios de maturidade sexual sugerem a ocorrência de desovas em um período prolongado, principalmente nos meses de temperaturas mais quentes, entre novembro e março. O tamanho médio de primeira maturação sexual foi estimado em $17,1 \mathrm{~cm}$ CP para as fêmeas e $16,9 \mathrm{~cm} \mathrm{CP}$ para os machos. O padrão de desenvolvimento dos ovócitos sugere que L. alexandrei exibe comportamento de múltiplas desovas por lote, e a fecundidade variou entre 34.000 a 324.000 ovócitos.

Key words: Multiple spawning, Oocytes, Sexual maturity, Spermatogenic cells.

\section{Introduction}

The snappers (Lutjanidae) are an important component of reef fisheries worldwide, with their catches representing about 90,000 t annually (Claro \& Lindeman, 2004; FAO, 2009). In Brazil, red snappers are mainly exploited by artisanal fisheries with an annual production of about 9,000 t that represents $10 \%$ of the world catches (Resende et al., 2003; Estatpesca, 2006). The Brazilian snapper, Lutjanus alexandrei, is an endemic species found in a limited area from Maranhão to Bahia, northeastern Brazil. Like other lutjanids, it is a smallsize species common in mangroves, rocks and shallow reefs near shore (Moura \& Lindeman, 2007).

Along the past decade, the trap fishing on the spotted goatfish Pseudupeneus maculatus increased which in turns fostered the fishing pressure on the Brazilian snapper populations as well, since these latter are often caught as bycatch in the goatfish fishery (Lessa et al., 2004; pers. obs.). The stocks of lutjanids off northeastern Brazil, however, are already under critical condition (Fredou et al., 2009); therefore, raising concerns emerged on the sustainability of the lutjanid artisanal fishery.

Studies on the reproductive biology of lutjanid species (L. analis, L. jocu, L. synagris, and Romboplites aurorubens) off northeastern Brazil indicated these species exhibit multiple batch spawning, asynchronous oocyte development, and a long spawning season spread out between spring and summer (Ferreira et al., 2004; Freitas et al., 2011). Up to now, however, almost nothing has been published on the biology of the Brazilian snapper, L. alexandrei, partly due to the fact that it is an endemic species that has been only recently described (Moura \& Lindeman, 2007).

Universidade Federal Rural de Pernambuco, Departamento de Pesca e Aquicultura, Laboratório de Oceanografia Pesqueira, rua Dom Manoel de Medeiros s/n, Dois Irmãos, 52171-900 Recife, Pernambuco, Brazil. cezaraff@hotmail.com 
The aim of this paper was to determine the reproductive dynamics of this still poorly known species, including a description of the development of oocytes and spermatogenic cells, size at first sexual maturity, spawning pattern and batch fecundity.

\section{Material and Methods}

A total of 540 fish were obtained from trap fishing landings in Itamaracá Island, northern coast of Pernambuco State, Brazil, from January 2008 to December 2009. About 25 fish, on average, were examined monthly. The total length (TL), standard length (SL), total weight (TW), gutted weight (GW), and gonad weight (GoW) were measured per fish. Fish gonads were evaluated macroscopically for sex and maturation stages, and then fixed in $4 \%$ formalin solution. To verify the maturity stages, a small section of the gonads of 250 fish (150 females and 100 males) were dehydrated (alcohol), cleared (xylene), embedded in paraffin, sectioned in microtome $(5 \mu \mathrm{m})$ and then stained (hematoxylin-eosin).

Microscopic characterization of gonad development was adapted as suggested by Hunter et al. (1985) and Kjesbu et al. (2003). Six maturity stages were established for females and males, as follows: immature, maturing, mature, spawning, spawned, and resting (Table 1). Fish sex ratio was tested monthly and annually for statistical differences $(\mathrm{p}<0.05)$ using chi-square $\left(\chi^{2}\right)$. Differences between sex for standard length and eviscerated weight over size range was tested through Kolmogorov-Smirnov $(\mathrm{p}<0.05)$.

The gonadosomatic index (GSI) was estimated by the equation: $\mathrm{GSI}=\mathrm{GoW} / \mathrm{GW} * 100$ (Maddock \& Burton, 1998), where $\mathrm{GoW}=$ gonad weight in grams (g), and $\mathrm{GW}=$ gutted weight in grams (g). Immature specimens were not included in the analysis. Size at first sexual maturity $\left(\mathrm{L}_{50}\right)$ was estimated from a logistic curve based on the relative frequency of adults in each length class (SL), according to the formula $\mathrm{M}_{\mathrm{f}}=\exp [\mathrm{a}+(\mathrm{b}) * \mathrm{SL}) /(1+\exp$ $(a+(b) * S L)]$, where $M_{f}$ is the fraction of adult specimens. All individuals in vitellogenesis were considered as adults. The fit of points was done by the method of maximum likelihood.

In order to assess the spawning pattern, the oocyte diameters from 30 ripe females were estimated by stereomicroscope, following Hunter et al. (1985). To estimate batch fecundity, the gravimetric methodology of Hunter \& Macewicz (1985) and Murua et al. (2003) was applied where the number of hydrated oocytes in a small section $(0.01 \mathrm{~g})$ of the gonad of 30 ripe females was counted, with batch fecundity being then calculated by the following formula: $\left.\mathrm{BF}=\left[\left(\mathrm{H}_{\mathrm{i}} / \mathrm{W}_{\mathrm{i}}\right) / \mathrm{n}\right) * \mathrm{GoW}\right]$, where: $\mathrm{H}_{\mathrm{i}}=$ number of oocytes from each portion, $\mathrm{W}_{\mathrm{i}}=$ weight of each portion of the ovary, $\mathrm{n}=$ number of repetitions, $\mathrm{GoW}=$ weight of each ovary.

\section{Results}

Of the 540 Brazilian snapper examined, 213 were females $(39.4 \%)$ and $327(60.6 \%)$ were males with these latter. Males were more abundant in the total sample $\left(\chi^{2}=24.0666, p<0.05\right.$, $\mathrm{df}=11)$, which produced a male biased sex ratio (1.6 males: 1.0 females). Males were more abundant in February $\left(\chi^{2}=5.4615\right.$, $\mathrm{p}<0.05, \mathrm{df}=1)$ and August $\left(\chi^{2}=6.4606, \mathrm{p}<0.05, \mathrm{df}=1\right)$.

There were no significant differences in body standard length between sexes (male standard length ranged 13.0 and $25.4 \mathrm{~cm} \mathrm{SL}$ and females 14.3 and $28.3 \mathrm{~cm} \mathrm{~S}$ ). There was not significant difference among sex along months or in gutted weight (Kolmogorov-Smirnov test; $\mathrm{p}>0.05$ ) (Fig. 1a-b).

Mature but not active females, with the majority of oocytes in protein vitellogenesis but no hydrated oocytes present (Fig. 2a), were mainly found from October to March. Spawning females, with many hydrated oocytes (Fig. 2b), were recorded manly from November to March, and spawning males were found only from November to March. Spawned females, with the presence of post-ovulatory follicles (Fig. 2b), were found just from January to April.

Both males and females in resting stage, in turn, were observed only from April to September. In the beginning of this period, ovaries had typically many oocytes in $\alpha$-atresia and $\beta$-atresia, indicating the end of spawning season, while more towards the end of it, ovaries presented only previtellogenic oocytes in atresia (Fig. 2c-3).

The monthly mean gonadosomatic indices (GSI) for both sexes were higher from November to March, peaking in January, and lower from April to October, with the lowest value in June (Fig. 4).

Length at first sexual maturity $\left(\mathrm{L}_{50}\right)$ was estimated at 17.1 $\mathrm{cm} \mathrm{SL}$, for females $(\mathrm{y}=\exp [-35.478+(2.0706) * \mathrm{SL}) /(1+\exp (-$

Table 1. Maturity development gonad stage (males and females) for the Brazilian snapper Lutjanus alexandrei. Data in parentheses represent the range of values for the gonad weight and gonadosomatic index.

\begin{tabular}{|c|c|c|}
\hline Maturity Stages & Microscopic characteristic of testis & Microscopic characteristic of ovaries \\
\hline ture & $\begin{array}{l}\text { Spermatocytes in early leptotenic, zygotenic and pactenic } \\
\text { phases }(0.1-1 \mathrm{~g}, \mathrm{GSI}=0.01-0.42)\end{array}$ & $\begin{array}{l}\text { Abundance of previtellogenic oocytes, no yolked oocytes and no } \\
\text { atresia. }(0.1-1 \mathrm{~g}, \mathrm{GSI}=0.1-0.45)\end{array}$ \\
\hline Mat & $\begin{array}{l}\text { Spermatocytes in metaphase I e II. Abundance of spermatids } \\
\text { and some rare spermatozoans }(1.0-2.7 \mathrm{~g}, \mathrm{GSI}=1.0-1.5)\end{array}$ & $\begin{array}{l}\text { Vitellogenic oocytes present and high abundance of previtellogenic } \\
\text { oocytes, no hydrated oocytes. }(1.0-3.0 \mathrm{~g}, \mathrm{GSI}=1.0-1,7) \\
\end{array}$ \\
\hline ature & $\begin{array}{l}\text { rmatids phase and high presence of spermatozoans. (3.0 } \\
\text { GSI }=1.8-2.2)\end{array}$ & $\begin{array}{l}\text { All major of oocytes in protein and lipid vitellogenesis, and rare } \\
\text { hydrated oocytes. }(3.0-7.4 \mathrm{~g}, \mathrm{GSI}=1.8-2.2)\end{array}$ \\
\hline ng & $\begin{array}{l}\text { Emptying of spermatogenic and still have many } \\
\text { spermatozoans. }(7.0-12.3 \mathrm{~g}, \mathrm{GSI}=2.0-2.5)\end{array}$ & $\begin{array}{l}\text { Hydrated oocytes and rare newly post-ovulatory follicles. }(8.0-19.4 \\
\mathrm{g}, \mathrm{GSI}=2.0-2.7)\end{array}$ \\
\hline Spav & $\begin{array}{l}\text { Rare of spermatozoans in vas deferens. }(6.1-7.2 \mathrm{~g}, \mathrm{GSI}=1.0- \\
1.4)\end{array}$ & POF abundance; little hydrated oocytes. $(6.7-9.4 \mathrm{~g}, \mathrm{GSI}=1.4-1.9)$ \\
\hline sting & $\begin{array}{l}\text { Disorganization in spermatogenics tubules and may empty } \\
\text { spaces between them. }(0.9-1.3 \mathrm{~g}, \mathrm{GSI}=0.5-0.92)\end{array}$ & $\begin{array}{l}\alpha \text {-atresia and } \beta \text {-atresia, no vitellogenic oocytes. Previtellogenic } \\
\text { oocytes abundance in atresia. }(1.0-1.6 \mathrm{~g}, \mathrm{GSI}=0.5-0.96)\end{array}$ \\
\hline
\end{tabular}


$35.478+(2.0706) * \mathrm{SL}])$, and $16.9 \mathrm{~cm} \mathrm{SL}$, for males $(\mathrm{y}=\exp [-$ $16.305+(.963556) * \mathrm{SL}) /(1+\exp (-16.305+(.963556) * \mathrm{SL}])$. However some males (3) with $15.5 \mathrm{~cm} \mathrm{~S}_{\mathrm{L}}$ already had sperm in the seminiferous tubules (Fig. 5).

The frequency distribution of oocyte diameter from 30 ripe spawning females (Fig. 6) showed in most cases 3 successive clutches which ranged between 12 to $1,040 \mu \mathrm{m}$. The first clutch (previtellogenic oocytes) had diameters varying between 12 to $108 \mu \mathrm{m}$, the second clutch (advanced yolked oocytes) ranged from 380 to $640 \mu \mathrm{m}$, and the third clutch (hydrated oocytes) from 720 to $1,040 \mu \mathrm{m}$. The asynchronous oocytes development and no hiatus observed between clutches, as presence of hydrated oocytes both post-ovulatory follicles evidences batch spawning.

Batch fecundity estimation from 30 ripe spawning females, with size ranging from 19 to $23.5 \mathrm{~cm} \mathrm{SL}$, varied between 33,990 and 323,738 oocytes.

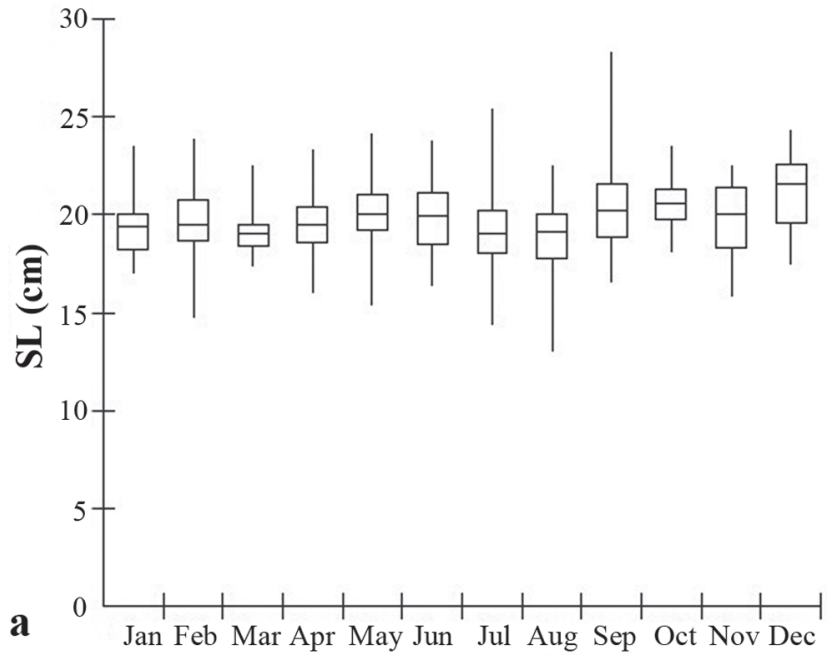

Months

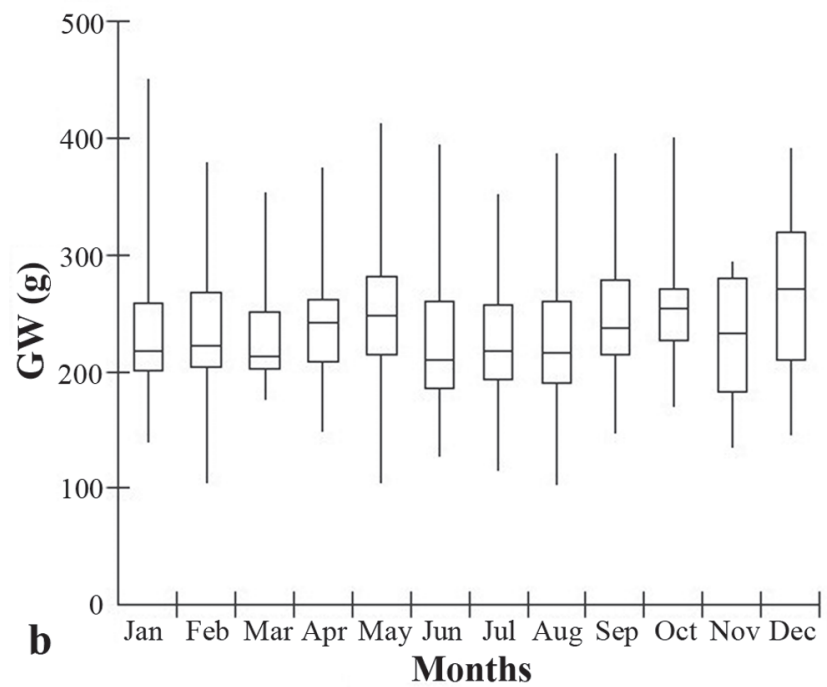

Fig. 1. (a) Variation by month for standard length (SL) for grouped sex. (b) Variation by month for gutted weight (GW) for grouped sex.
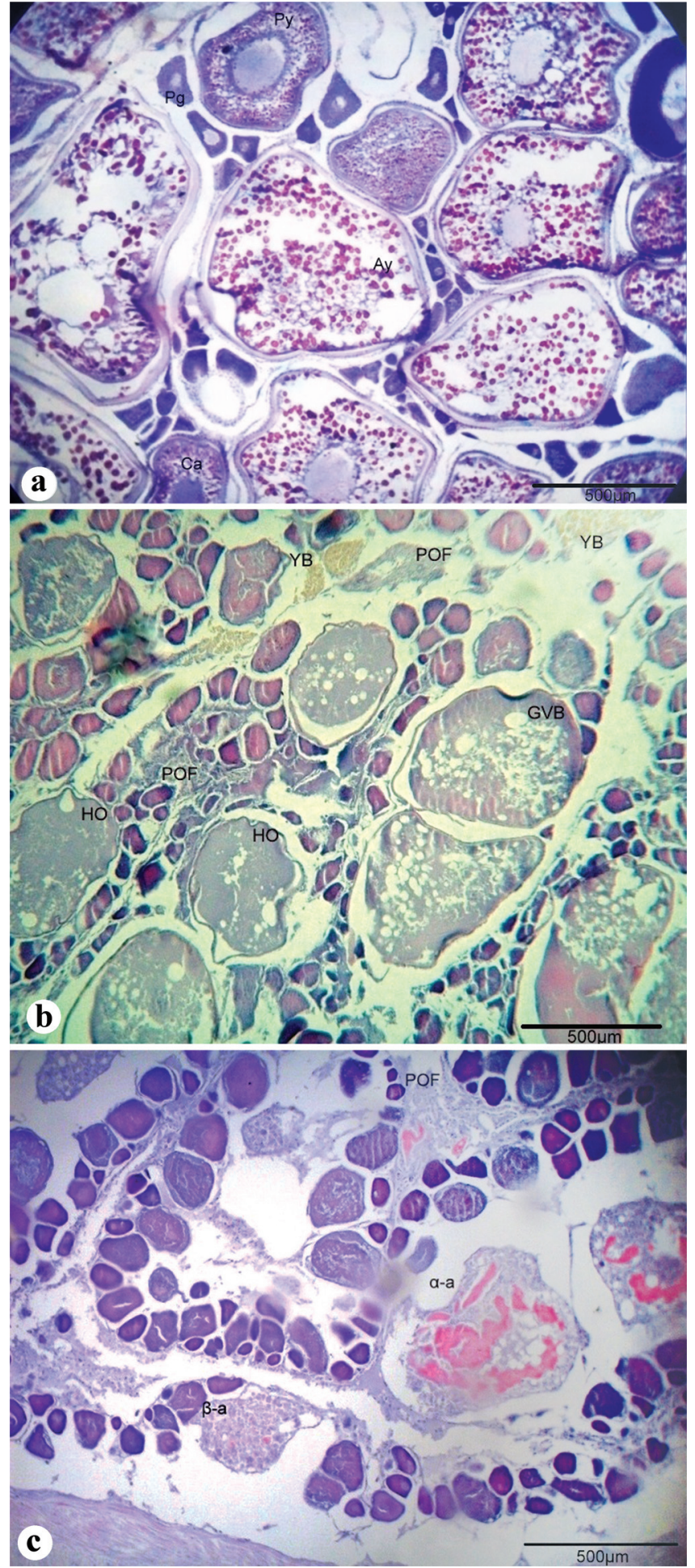

Fig. 2. Histological section of a female gonad of $L$. alexandrei showing (a) Oocyte from a fully developed mature female with: primary growth $(\mathrm{Pg})$, cortical alveoli $(\mathrm{Ca})$, partially yolked (Py), and advanced yolked (Ay) oocytes (100X+3.0.Opitical Zoom); (b) Oocytes from a spawning female with: hidratated oocyte (Ho), germinal vesicle breakdown (GVB), post-ovulatory follicles (POF) and Yellow bodies (YB) $(100 \mathrm{X}+2.0$.Opitical Zoom); (c) Oocytes from a fully spent ovary with $\alpha$ and $\beta$-atresia e even $\mathrm{POF}(100 \mathrm{X}+2.0$.Opitical Zoom $)($ Scale bar $=500 \mu \mathrm{m})$. 

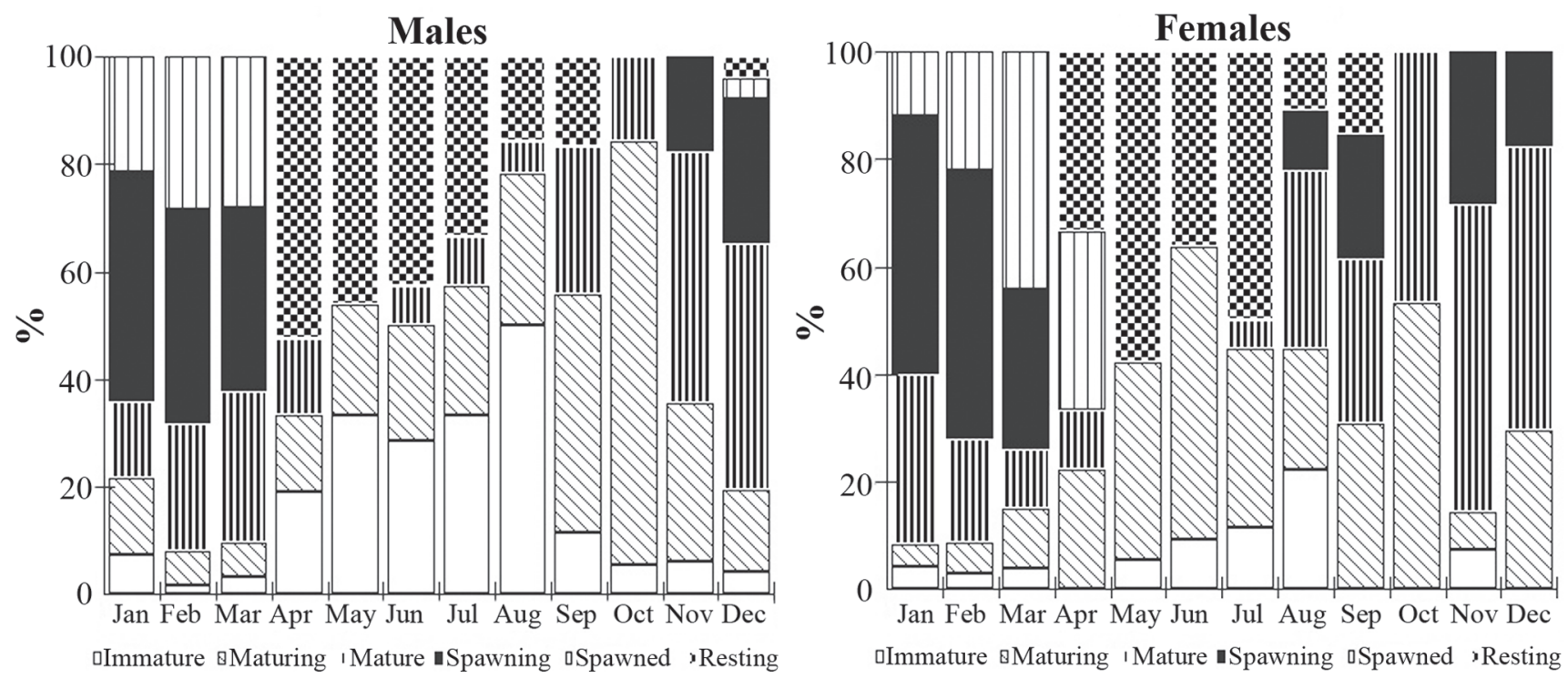

Fig. 3. Monthly variation for maturity stages (immature, maturing, mature, spawning, spawned, and resting) for males and females.

\section{Discussion}

In most snapper species, females are larger and more abundant than males (Allman et al., 2002). In the present study on the Brazilian snapper Lutjanus alexandrei, however, males were more abundant on the total sample (sex ratio of 1.6:1.0). But male biased sex ratios not occur in all months, except in February and August. Male dominance is common in other snappers in the other regions, such as $L$. argentiventris (2.0:1.5) in Colombia and L. guttatus (1.3:1.0) in Costa Rica (Torres, 1996; Rojas, 1997). Starck (1971) reported that males of L. griseus in Florida are generally more abundant in reef areas around islands while females are more abundant in coastal areas due to their spawning behavior. Some snappers, however, spawn in offshore aggregations and usually a paired sex ratio is more common (Carter \& Perrine, 1994; Domeier \& Colin, 1997).

The harem behavior occurs in small snappers, with a single female attracting 5-8 males previous to spawning (Hamammoto et al., 1992). On large bodied lutjanids paired sex ratios in monogamy systems is commonly found (Grimes, 1987). The Brazilian snapper is a small-bodied fish and both sexes showed same size range during all year, even on spawning months. Sex ratios above 1:1 for majority of months along year make us to opinion in a paired spawning behavior, also due the spawning aggregation in off shore reefs where traps are setting.

Temporal variability in seasonal spawning on lutjanids had been widely discussed. Usually, coastal species show protracted spawning seasons during summer while insular
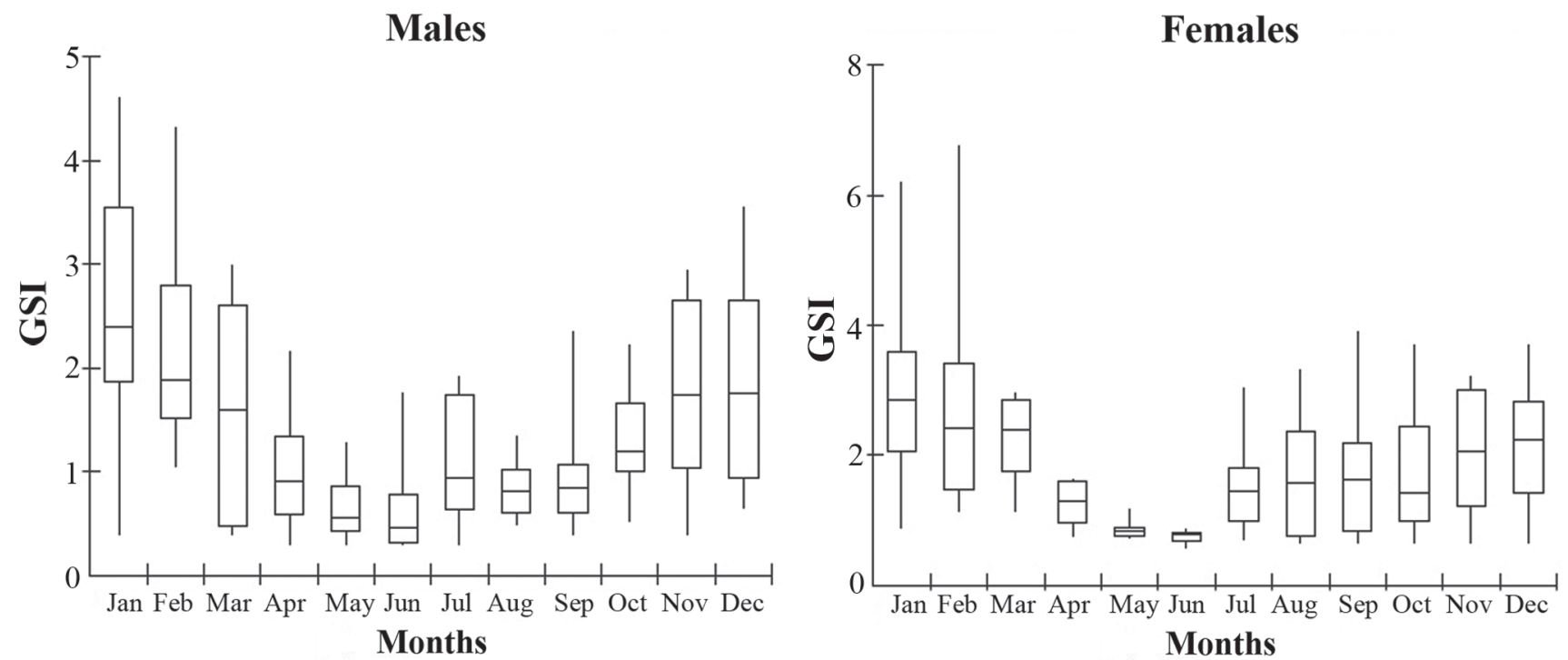

Fig. 4. Monthly Gonadosomatic Index (GSI) for males and females. 


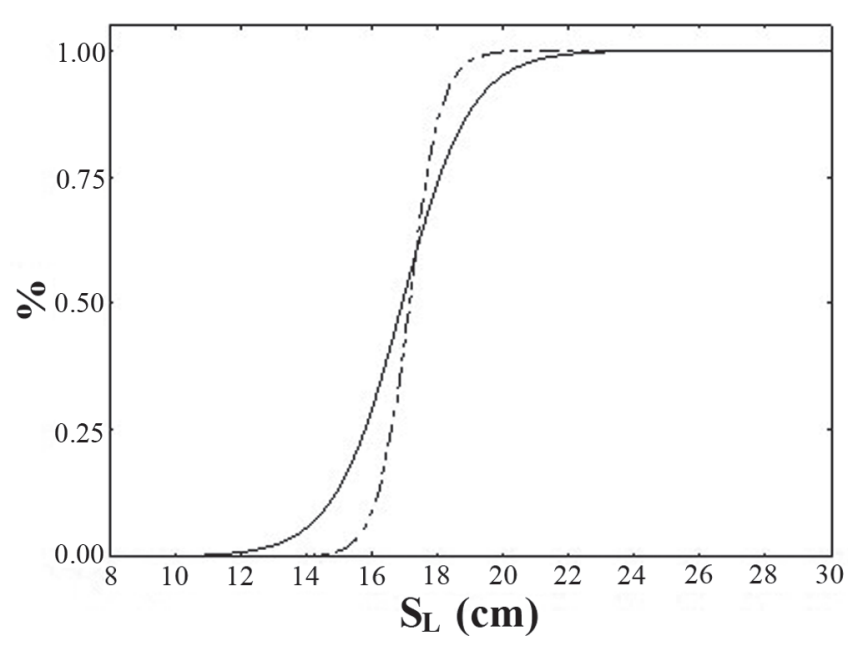

Fig. 5. First size of sexual maturity $\left(\mathrm{L}_{50}\right)$ for males (full line) and females (dashed line).

populations tend to reproduce throughout the year (Grimes, 1987; Claro and Lindeman, 2004; Grandcourt et al., 2006).

The Brazilian snapper has a very clear spawning season, spreading along the warmer months, from November to March, with a peak in February. A similar spawning season is found in many Brazilian lutjanids and other tropical pelagic fishes (Ferreira et al., 2004; Freitas et al., 2011). Curiously, a long spawning season, like insular populations, occurs for coastal lutjanids in northeastern of Brazil, possibly due to warm waters during almost all year and increment in richness from estuaries on food web (Claro \& Lindeman, 2004). Landings from trap fishing show an markedly increase in the same period, probably due to spawning aggregations, which makes Brazilian snapper more vulnerable to fishing (Lessa et al., 2004).

The asynchronous development, presence of oocytes in different stages in mature females, as observed in Brazilian snapper, indicates a multiple batch spawning in a protracted spawning season, as reported for many tropical fishes (Hunter et al., 1985). Although, a synchronous development of oocytes similar like occurs on total spawned species, following by an asynchrony during ovulation, and batch-spawning events have been observed in snappers in Cuba, presumably because of a short marked summer season (García-Cagide et al., 1994; 2001).

Shorts spawning periods for lutjanids were reported for $L$. fulviflamma in the Arabian Gulf, which is associated with an increase of water temperature (Grandcourt et al., 2006). The Brazilian snapper seems to be a serial multiple spawning throughout warm months, due to the simultaneous presence of post ovulatory follicles, yellow bodies and hydrated oocytes in ripe spawning females. These structures are indicators of past spawning and egg prior (Hunter \& Macewicz, 1985).

On the frequency of oocyte diameter for Brazilian snapper, it was possible to observe successive clutches in different development stages on ripe spawning females. During the spawning season, oocytes from reserve stocks still permanently recruited. Multiple spawning is an adaptation to

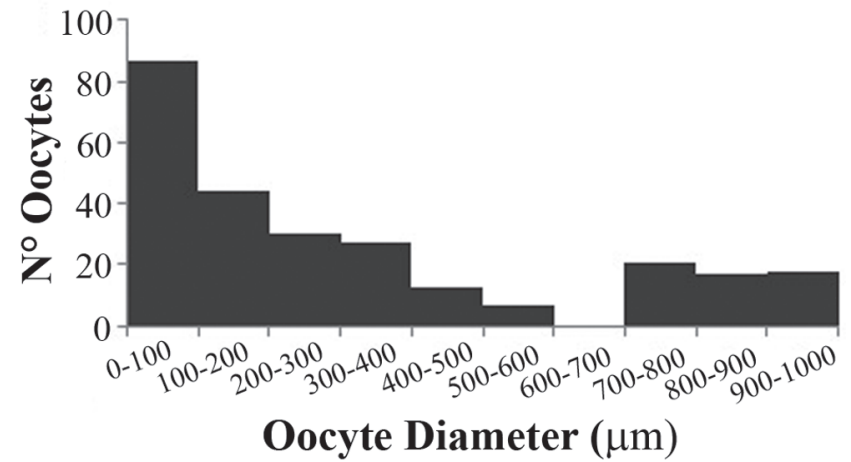

Fig. 6. Frequency of oocytes diameter from 30 ripe spawning females.

increase egg potential survival for reef fish species that do not have any parental care and whose larvae are dispersed (Petersen \& Warner, 2002).

The batch fecundity in the Brazilian snapper (between 33,990 and 323,738 oocytes) is relatively similar to that of other small snappers worldwide, such as L. fulviflamma, in Tanzania $(51,000$ to 460,000 oocytes) (Kumukuru \& Magaya, 2004), and $L$. carponotatus, in the Great Barrier Reef, in Australia $(7,074$ to 748,957 ) (Evans et al., 2007). Fecundity is regulated in response to environmental conditions, food availability nutrition, predation, and energetic resources to reproductive success (Kjesbu et al., 2003). The snappers, similar to many pelagic fishes show a high fecundity to compensate dispersal eggs (Claro et al., 1999).

Grimes (1987) reported that size at first sexual maturity for snappers corresponds approximately to $50 \%$ of the maximum size of the species. Considering that the size at first sexual maturity was estimated at $17.1 \mathrm{~cm} \mathrm{~S}_{\mathrm{L}}$ and $16.9 \mathrm{~cm} \mathrm{~S}_{\mathrm{L}}$ for females and males, respectively, for Brazilian snapper, then its maximum size might be close to $34 \mathrm{~cm}$, a length not far from the maximum size recorded in the present work $(25.4 \mathrm{~cm}$ SL for males and $28.3 \mathrm{SL} \mathrm{cm}$ for females).

Data from the Brazilian snapper in Pernambuco, Brazil, may contribute on a management plan. The length at first sexual maturity, spawning season, and spawning patterns estimated in this study can be used to propose management and conservation strategies for this endemic species.

\section{Acknowledgements}

We would like to thank CAPES (Coordenação de Aperfeiçoamento de Pessoal de Nível Superior) for supporting this research and the Fishery Resources and Aquaculture from the Department of Fishery and Aquaculture from Universidade Federal Rural de Pernambuco, Brazil.

\section{Literature Cited}

Allman, R. J., L. A. Lombardi-Carlson, G. R. Fitzhugh \& W. A. Fable. 2002. Age structure of red snapper (Lutjanus campechanus) in the Gulf of Mexico by fishing mode and region. Proceedings of Gulf Caribbean Fishery Institute, 53: 482-495. 
Carter, J. \& D. Perrine. 1994. A spawning aggregation of dog snapper, Lutjanus jocu (Pisces: Lutjanidae) in Belize, Central America. Bulletin of Marine Science, 55: 228-234.

Claro, R., L. M. Sierra Sierra \& J. P. Garcia Arteaga. 1999. Biology of the dog snapper Lutjanus jocu in the NE and SW zones of Cuban shelf. Revista de Investigaciones Marinas, 20: 30-38.

Claro, R. \& K. C. Lindeman. 2003. Spawning aggregations sites of snapper and grouper (Lutjanidae and Serranidae) species on the insular shelf of Cuba. Gulf Caribbean Research, 14: 91-106.

Claro, R. \& K. C. Lindeman. 2004. Biología y manejo de los pargos (Lutjanidae) en el Atlántico occidental. Instituto de Oceanología, Instituto de Geofisíca y Astronomía, Ministerio de Ciencia, Tecnología y Medio Ambiente, La Habana, 472p.

Domeier, M. L. \& P. L. Colin. 1997. Tropical reef fish spawning aggregations: defined and reviewed. Bulletin of Marine Science, 60: 698-700.

Estatpesca. 2006. Boletim Estatístico da Pesca Marítima e Estuarina do Nordeste do Brasil. Centro de Pesquisa e Gestão de Recursos Pesqueiros do Litoral Nordeste (CEPENE), Pernambuco, 384p.

Evans, R. D., G. R. Russ \& J. P. Kritzer. 2007. Batch fecundity of Lutjanus carponotatus (Lutjanidae) and implications of no-take marine reserves on Great Barrier Reef, Australia. Coral Reefs, 27: $179-189$.

FAO. 2009. The State of World Fisheries and Aquaculture. FAO Fisheries and Aquaculture Department. Food and Agriculture Organization of the United Nations. Rome, 187p.

Ferreira, B. P., S. M. Rezende, S. F.Teixeira, T. Fredou \& Y. Duarte Ferreira. 2004. In: Lessa, R. P., M. F. de Nóbrega \& J. L. Bezerra Junior. Dinâmica de Populações e Avaliação dos Estoques dos Recursos Pesqueiros da Região Nordeste. REVIZEE (Programa de Avaliação Sustentável dos Recursos Vivos da Zona Econômica Exclusiva do Brasil), Recife, 246p.

Frédou, T., B. P. Ferreira \& Y. Letourneur. 2009. Assessing the stocks of the primary snappers caught in Northeastern Brazilian reefs systems. 1: Traditional modeling approaches. Fisheries Research, 99: 90-96.

Freitas, M. O., R. L. de Moura, R. B. Francini-filho \& C. V. MinteVera. 2011. Spawning patterns of commercially important reef fish (Lutjanidae and Serranidae) in the tropical western South Atlantic. Scientia Marina, 75: 135-146.

García-Cagide, A., R. Claro, \& B. V. Koshelev. 1994. Reproducción. Pp. 187-262 In: Claro, R. (Ed.). Ecología de los peces marinos de Cuba. Instituto de Oceanología, Academia de Ciencias de Cuba y Centro de investigaciones de Quintana Roo, México, 525p.

García-Cagide, A., R. Claro \& B. V. Koshelev. 2001. Reproductive patterns of Fishes of the Cuban Shelf. Pp. 73-114. In: Claro, R., K. C. Lindeman \& L. R. Parenti (Eds.). Ecology of the Marine Fishes of Cuba. Washington and London, Smithsonian Institution Press, 253p.

Grandcourt, E. M., A. L. Abdessalaam \& T. Z. Francis. 2006. Age, growth, mortality and reproduction of the blackspot snapper, Lutjanus fulviflamma (Forsskal, 1750), in the southern Arabian Gulf. Fisheries Research, 78: 203-210.

Grimes, C. B. 1987. Reproductive biology of the Lutjanidae: a review. Pp. 239-294. In: Polovina, J. J. \& S. Ralston (Eds.). Tropical snappers and groupers: biology and fisheries management. Ocean Resource and Marine Policy Service. Boulder and London, Westview Press, 347p.

Hamammoto, S., S. Kumagai, K. Nosaka, S. Manabe, A. Kasuga \& Y. Iwatsuki. 1992. Reproductive behavior, eggs and larvae of a Lutjanidae Fish, Lutjanus stellatus, observed in an aquarium. Japanese Journal of Ichthyology, 39: 3-11.
Hunter, J. R. \& B. Macewicz. 1985. Sexual maturity, batch fecundity, spawning frequency and temporal pattern in the northern anchovy, Engraulis mordax, during the 1979 spawning season. California Cooperative Oceanic Fisheries Investigations Report, 21: 139-149.

Hunter, J. R., N. C. H. Lo \& R. J. H. Leong. 1985. Batch fecundity in multiple spawning fishes. In: Lasker, R. (Ed.). An egg production method for estimating spawning biomass of pelagic fish: application to the Northern Anchovy, Engraulis mordax. NOAA Technical Report NMFS, 36: 67-77.

Kamukuru, A. T. \& Y. D. Mgaya. 2004. Effects of exploitation on reproductive capacity of black-spotted snapper, Lutjanus fulviflamma (Pisces: Lutjanidae) in Mafia Island, Tanzania. African Journal of Ecology, 42: 270-280.

Kjesbu, O. S., K. R. Y. V. I. H. Klungsoyr, P. R. Witthames \& M. G. Walker. 1991. Fecundity, atresia, and egg size of captive Atlantic cod (Gadus morhua) in relation to proximate body composition. Canadian Journal of Fisheries and Aquatic Sciences, 48: 2333-2343.

Kjesbu, O. S., J. R. Hunter \& P. R. Witthames. 2003. Modern approaches to assess maturity and fecundity of warm-and cold-water fish and squids. Report on the Working Group, Bergen, 137p.

Lessa, R. P., M. F. de Nóbrega \& J. L. Bezerra Junior. 2004. Dinâmica das frotas pesqueiras da região Nordeste do Brasil. Análise das principais pescarias. Programa de Avaliação Sustentável dos Recursos Vivos da Zona Econômica Exclusiva do Brasil (REVIZEE), Recife, 158p.

Maddock, D. M. \& M. P. Burton. 1998. Gross and histological of ovarian development and related condition changes in American plaice. Journal of Fish Biology, 53: 928-944.

Moura, R. L. \& K. C. Lindeman. 2007. A new species of snapper (Perciformes: Lutjanidae) from Brazil, with comments on distribuition of Lutjanus griseus and L. apodus. Zootaxa, 1422: 31-43.

Murua, H., G. Kraus, F. Saborido-Rey, P. R. Witthames, A. Thorsen \& S. Junquera. 2003. Procedures to estimate fecundity in fishes. Journal of Northwest Atlantic Fishery Science, 33: 33-54.

Petersen, C. W. \& R. R. Warner. 2002. The ecological context of reproductive behavior. Pp. 103-118. In: P. F. Sale (Ed.). Coral Reef Fishes: Dynamics and Diversity in a Complex Ecosystem. California, Academic Press, 543p.

Resende, S. M., B. P. Ferreira \& T. Frédou. 2003. Boletim Técnico Científico. Centro de Pesquisa e Gestão de Recursos Pesqueiros do Litoral Nordeste (CEPENE), 11: 257-270.

Rojas, M. J. R. 1997. Fecundidad y épocas de reproducción Del "pargo mancha" Lutjanus guttatus (Pisces: Lutjanidae) em el Golfo de Nicoya, Costa Rica. Revista de Biología Tropical, 44: 477-487.

Starck, W. A. II. 1971. The biology of the grey snapper, Lutjanus griseus (Linnaeus), in the Florida Keys. In: Starck II, W. A \& R. E. Schroeder. Investigations on the gray snapper, Lutjanus griseus. Studies in Tropical Oceanography 10, Rosenstiel School of Marine and Atmospheric Sciences, University of Miami Press, Florida, 150p.

Torres, C. A. 1996. Aspectos biológico-pesqueros del pargo palmero Lutjanus argentiventris (Peters, 1869) y reconocimiento sobre la pesca artesanal en el municipio de Bahía Solano (ChocóColombia). Informe Técnico Instituto Nacional de Pesca y Acuicultura INPA, Colombia, 16p.

Submitted December 10, 2012 Accepted August 14, 2012 Published September 28, 2012 